\title{
Religiosität als Qualität des Säkularen
}

\author{
Die Religionstheorie John Deweys
}

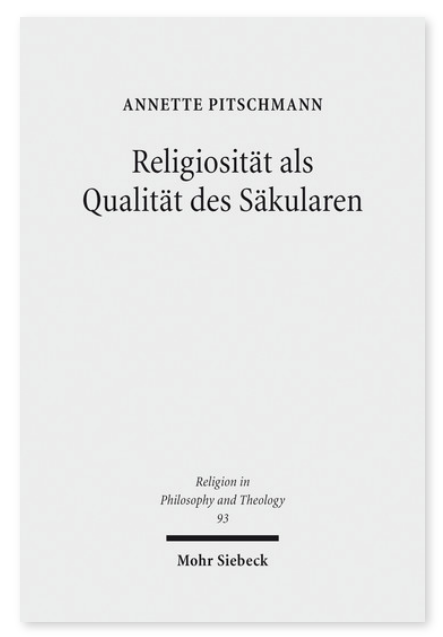

2017. IX, 348 Seiten. RPT 93

ISBN 978-3-16-154844-4

DOI 10.1628/978-3-16-154844-4

eBook PDF $94,00 €$

ISBN 978-3-16-154843-7

fadengeheftete Broschur $94,00 €$
Im Diskurs über die legitime Rolle der Religion in der demokratischen Öffentlichkeit wird vielfach unterstellt, religiöse und säkulare Denkformen ließen sich anhand ihrer metaphysischen Vorannahmen einschlägig gegeneinander abgrenzen. Das dabei angewandte Kriterium - die Frage, inwieweit eine transzendente Realität vorausgesetzt wird - wird dabei oftmals zugleich als Indiz der Inkompatibilität des religiösen und des säkularen Denkens gedeutet.

Der Pragmatist John Dewey hat in der ersten Hälfte des 20. Jahrhunderts eine Religionstheorie vorgelegt, die angesichts dieser Tendenz zur Dichotomisierung von der Leitdifferenz zwischen Transzendenz und Immanenz absieht. Auf diese Weise beansprucht er zu zeigen, dass Religiosität - recht verstanden - auf Voraussetzungen beruht, die ebenso allgemein zugänglich sind wie die Prämissen säkularen Lebens. Annette Pitschmann erschließt Deweys Religionstheorie vor dem Hintergrund seiner Wirklichkeitskonzeption und prüft ihre Plausibilität im Horizont von Deweys Wissenschafts- und Handlungstheorie sowie seiner Ästhetik.

Annette Pitschmann Geboren 1976; 1996-2004 Violoncello- und Theologiestudium in Frankfurt am Main, München und Oxford; 2009-14 Wissenschaftliche Mitarbeiterin für Religionsphilosophie an der Goethe-Universität Frankfurt am Main, währenddessen Promotion in Religionsphilosophie. Derzeit Forschungstätigkeit an der Paris-Lodron-Universität Salzburg sowie Tätigkeit in der katholischen Erwachsenenbildung.

Jetzt bestellen:

https://mohrsiebeck.com/buch/religiositaet-als-qualitaet-des-saekularen-9783161548444?no_cache=1 order@mohrsiebeck.com

Telefon: +49 (0)7071-923-17

Telefax: +49 (0)7071-51104 